\title{
Rodina Vilinských v Československu: Valerij Vilinskij k některým jevům české literatury
}

\author{
Ivo Pospíšil (Brno)
}

\begin{abstract}
Abstrakt
Autor př́tomného příspěvku se zabývá životem a dílem Sergije Vilinského a Valerije Vilinského - otce (ruského profesora) a syna (politologa a novináře) v meziválečném Československu. Analyzuje dílo syna Valerije a soustředí se na jeho studie o české katolické literatuře, zejména o díle Otokara Březiny, Jaroslava Durycha a Jakuba Demla v česky psané knize Rus se dívá na Č. S. R. a v polsky psaných studiích publikovaných v Krakově. Katolickou literaturu, stejně jako celou katolickou komunitu v meziválečném Československu autor chápe jako osobitou uzavřenou enklávu a zabývá se jí izolovaně, aniž vidí spojitosti její poetiky s avantgardními proudy, které v první polovině 20. století v české literatuře dominovaly. Nicméně jeho koncepce anticipuji některé názory, které se objevily až v první trětině 21 . století.
\end{abstract}

\section{Klíčová slova}

Sergij Vilinskij a Valerij Vilinskij - otec a syn v meziválečném Československu; tragický osud a dílo Valerije Vilinského; jeho studie o Březinovi, Durychovi a Demlovi česky a polsky; jeho přliš uzavřená enkláva katolické literatury; absence spojitosti s avantgardní poetikou; anticipace budoucích koncepcí

\section{Abstract \\ The Vilinskii Family in Czechoslovakia: Valerii Vilinskii on Some Phenomena of Czech Literature}

The author of the present contribution deals with the lives and works of both Sergii Vilinskii and Valerii Vilinskii - father (Russian professor) and son (political scientist and journalist) - in interwar Czechoslovakia. He analyzes the work of the son Valerii focusing on his studies in Czech Catholic literature, especially on the work of Otokar Březina, Jaroslav Durych, and Jakub Deml in the book written in Czech A Russian Looks at Czechoslovak Republic and on the studies written in Polish and published in Cracow. Catholic literature as well as the Catholic community in interwar Czechoslovakia is understood as a specific, closed enclave analysed as an isolated entity without regard to the connection of its poetics with avantgarde currents which in the first half of the $20^{\text {th }}$ century dominated. Nevertheless, his concepts anticipate some views which appeared only in the first third of the $21^{\text {st }}$ century.

\section{Key words}

Sergii Vilinskii and Valerii Vilinskii - father and son in interwar Czechoslovakia; tragic fate and work of Valerii Vilinskii; his studies in Březina, Durych and Deml in Czech and Polish; his overly closed enclave of Catholic literature; absence of the connection with avantgarde poetics; anticipation of future concepts 
$\mathrm{Na}$ počátku třeba uvést celou problematiku partií o otci a synovi. ${ }^{1}$ Mezi ruskými porevolučními emigranty, kteří působili na území meziválečného Československa, později Protektorátu Čechy a Morava a Slovenské republiky (od 14. 3. a 15. 3. 1939), byli i prof. Sergij Vilinskij a jeho syn Valerij. Jde o příběh otce a syna, kteří profesně zakotvili v Brně a Praze, ale oba úzce spolupracovali i se Slovenskem. Bylo to logické: Praha a Brno je lákaly, nebot to byla tehdy vzdělanostní a vědecká centra, navíc v Praze a celých Čechách a na Moravě žila řada ruských emigrantů podporovaných v rámci Ruské podpůrné akce, ale Slovensko jim oběma bylo ideově bližší, nebot zde našli pevné náboženské zázemí: oba byli sice pravoslavní, ale lákal je zejména katolicismus a Valerij byl velkým propagátorem ekumenismu.

Zatímco Sergij Vilinskij získaný profesory Stanislavem Součkem (1870-1935) a Václavem Vondrákem (1859-1925) pro Masarykovu univerzitu jako smluvní profesor zůstal částí své činnosti sice ukotven v medievistice, kterou pěstoval na Novorossijské univerzitě v Oděse, ale přece jen se musel odborně přeorientovat na modernější literaturu (M. J. Saltykov-Ščedrin, Petko Todorov) a snažil se sporadicky spolupracovat i s katolickými kruhy na Moravě, jeho syn Valerij pronikl do českého prostoru mnohem razantněji.

Střední Evropa byla od počátku 20. století křižovatkou myšlenkových proudů, a to i literárněvědných. Tento stav pokračoval i po vzniku Československé republiky, dokonce se ještě prohloubil ruskou Říjnovou revolucí a následnou emigrací intelektuálů. Na území meziválečného Československa se prolínaly vlivy ruské formální školy a jejího představitele Romana Jakobsona (1896-1982), který ruské kroužkaření přenesl na pưdu jím a Vilémem Mathesiem založeného Pražského lingvistického kroužku, pozitivismu, duchovědy a psychologických metod intuitivistického a neoidealistického ražení, z nichž vyrůstal mimo jiné René Wellek (1903-1995), jenž spolu s Jakobsonem přenášel pak tuto metodologickou bázi do USA. Do této složité, ale plodné atmosféry přichází v roce 1923 právě Sergij Grigorjevič Vilinskij, který si s brněnskými profesory již dříve vyměňoval publikace. V jeho osobnosti se dotváří systém východozápadního a severojižního myšlenkového proudění: sám byl mimořádným a později řádným profesorem a prorektorem Oděské Novorossijské univerzity.

Z životopisu, který sám napsal vlastní rukou česky a datoval 24. 3. 1935 (v souvislosti se žádostí o složení přísných zkoušek doktorských, nebot’ titulu doktora ruské literatury, který mu byl udělen v Oděse roku 1914, nemohl u nás podle tehdejších předpisů užívat), vysvítá, že se narodil v Kišiněvě (pocházel z polsko-ukrajinské rodiny), kde vystudoval klasické gymnázium roku 1895, pak byl krátce posluchačem petrohradského historicko-filologického institutu, od podzimu 1896 studoval na slovansko-ruském oddělení historicko-filologické fakulty Novorossijské univerzity v Oděse. Tam zahájil strmě vzestupnou vědeckou dráhu, která vrcholila v letech 1912-1914, kdy se stal prorektorem a řádným

1 Tato úvodní partie o otci a synovi Vilinských byla po̊vodně psána pro Almanach Nitra pod názvem $Z a$ jimavý osud ruských emigranti̊: otec a syn Sergij Vilinskij (1876-1950) a Valerij Vilinskij (1903-1955), zatím neuveřejněno. O V. Vilinském viz ještě naši studii: Ruský emigrant se dívá na meziválečné Československo a česko-slovenský vztah. In: Český a slovenský kulturní a politický prostor (vzájemnost - nevzájemnost, vstřícnost - rezistence, ústup - expanze). Ed. Ivo Pospíšil. Výkonná redaktorka Lenka Paučová. Brno: Česká asociace slavistů - Jan Sojnek, Galium, 2017. 
profesorem ruské literatury na základě obhajoby doktorské disertace Žitije sv. Vasilija Novago v russkoj literature. Z Ruska emigroval 7. 2. 1920 - v př́stavu mu před odplutím ukradli všechny kufry, takže i své vlastní knihy musel pak v Evropě shánět po antikvariátech. Tak začal jeho nelehká bulharská anabáze: učil na gymnáziu v Plevně, pak byl přeložen jako učitel latiny do Sofie, na gymnázium v Plovdivu už nešel a po jisté doby bez zaměstnání se stal bankovním úředníkem. V létě 1921 dostal nabídku od prof. Václava Vondráka, aby přednášel ruskou literaturu na tehdy nově založené Masarykově univerzitě. V listopadu 1921 byl zvolen smluvním profesorem Masarykovy univerzity a v dubnu 1923 jím byl ustanoven. Kromě profesorských povinností na Masarykově univerzitě přednášel také ruskou literaturu na ruském pedagogickém institutu v Praze až do jeho zrušení v roce 1927.

Odbornou doménou Sergije Vilinského v Rusku byla staroruská literatura. Jeho práce, mimo jiné Skazanija o Sofii Caregradskoj v jelinskom letopisce $i$ v Chronografe (1903), zmíněné Žitije Vasilija Novago v russkoj literature (1914), jimž předcházela jeho mezinárodně uznávaná prvotina Vizantijsko-slavjanskije skazanija o sozdanii chrama sv. Sofii Caregradskoj (1900), se pevně zapsaly do ruské medievistiky, rusistiky, slavistiky a byzantologie. V Bulharsku přišel do kontaktu nejen se středověkými prameny, ale také se soudobou bulharskou literaturou. I během pobytu v Brně pravidelně s finanční podporou českých úřadů pobýval na vědeckých stážích v Bulharsku. V Brně přesunul svůj zájem k novoruské literatuře - i vzhledem ke své úloze profesora ruské literatury, která předpokládala spíše soustředění na novou dobu. Jako téma své první „československé“ knihy si zvolil dílo Michaila Jevgrafoviče Saltykova-Ščedrina (O literární činnosti M. J. Saltykova-Š̌́edrina, Brno 1928). Z bulharských materiálů vytěžil monografii Petko Todorov (Život a dilo), kterou podal jako disertaci (vyšla pak roku 1933).

Pozoruhodná není ani tak Vilinského metodologie, která je směsí filologické metody medievistické, pozitivismu s př́měsí zájmu o sociologii a psychologii artefaktu a o literární morfologii (poetiku), ale to, že spojoval ruskou středověkou a novověkou literaturu, resp. nacházel stopy staroruské poetiky v nových dílech, která v žánru románu oslnila svět: právě M. J. Saltykov-Ščedrin (1826-1889) ve svém díle koncentroval těchto tradičních staroruských prvků značné množství. Práce pozdějšího koryfeje ruské literární medievistiky D. S. Lichačova i naší medievistky Světly Mathauserové jdou tedy vlastně ve stopách těchto inspirujících postupů Sergije Vilinského, jehož moravská bibliografie dokládá šîri jeho zájmů od tradic východní církve, národních prvků u I. S. Turgeněva po bulharsko-francouzské kulturní vztahy - pozoruhodný je také vztah Sergije Vilinského a jeho syna Valerije $\mathrm{k}$ autorovi prvních českých dějin ruské literatury, překladateli, rajhradskému mnichovi a faráři Aloisi Augustinu Vrzalovi (1864-1930): S. Vilinskij uveřejnil některé dopisy ruských spisovatelů adresované Vrzalovi (jeho pseudonym A. G. Stín vznikl z jeho klášterního jména Augustin) včetně dopisu-autobiografie A. P. Čechova.

Se Sergijem Vilinským jsou spojena ještě další významná jména, jimiž se stř̌edoevropský metodologický kruh svým způsobem uzavírá: v Oděse byl jeho žákem vynikající medievista N. K. Gudzij a v zimním semestru 1913 u něho studoval také Michail Bachtin (1895-1975), který pak přešel do Sankt-Petěrburgu (což vyvolává otázku, nakolik znalec antiky a středověku Vilinskij ovlivnil pozdější Bachtinovu orientaci). Zakladatel brněnské 
literárněvědné rusistiky, který dotvářel specifickou podobu brněnské slavistiky Franka Wollmana, je však také spojen s tradicemi ruské a české byzantologie. Z brněnských rusistů se k Sergiji Vilinskému vytrvale hlásil jeho žák doc. Jaroslav Mandát (1924-1986), který poslouchal Vilinského přednášky z ruského folklóru, staroruské a novoruské literatury a který mi jeho postavu svým barvitým vyprávěním přibližoval. Jeho Vzpomínka na $S$. G. Vilinského byla také patrně jeho posledním dílem. ${ }^{2}$

Valerij Vilinskij publikoval své práce rusky, česky i slovensky a týkaly se politiky, kultury a literatury. Jde o vynikající soubor textů, které jsou nejen dokladem proměny názorů ruské emigrace, ale také podnětnou analýzou poměrů v SSSR viděnými z dálky emigrace, ale také situaci v meziválečném Československu. Generační posun je tu patrný: komunikace s českým a slovenským prostředím, zejména s katolickým, ideje ekumenismu a studie o ruské revoluci jsou nejpřínosnější. Valerij Vilinskij se bohužel vyvíjel tragickým směrem: po válce byl vyšetřován pro podezření z kolaborace s německou mocí za Protektorátu Böhmen und Mähren, ale protože se zavázal k spolupráci s nově vzniklou Státní bezpečností a patrně i s NKVD, bylo šetření zastaveno: dokonce existují doklady, že sovětská strana by nebránila jeho návratu do SSSR, ale - na rozdíl například od A. Bema - nebyl tam unesen, aby navždy zmizel v některém z gulagů, ale stal se agentem, který významně pomohl k úspěšnému únorovému převratu z roku 1948. Jako tajemník ministra Ivana Pietory a známý řady tehdejších nekomunistických politiků přinášel vedení KSČ důležité informace. ${ }^{3} \mathrm{~S}$ jistou hyperbolou lze říci, že v řešení vládní

2 VILINSKIJ, Sergij: Národni prvky v tvorbě I. S. Turgeněva. In: Sborník družiny literární a umělecké k padesátým narozeninám p. Emanuela Masáka. V Olomouci, MCMXXXIII, s. 119-127; týž: O literárni činnosti M. J. Saltykova-Ščedrina. Brno: Masarykova universita, Filosofická fakulta, 1928; Petko Jur. Todorov. Život a dílo. Brno: Masarykova universita, Filosofická fakulta, 1933; Pis 'ma russkich pisatelej češskomu perevodčiku. Iz archiva Avg. Vrzala. Praha: Central'naja Jevropa, 1930, 11, s. 650-657. Další dopisy ruských spisovatelů a kulturních činitelů A. Vrzalovi publikovali J. Mandát a I. Pospíśil (viz POSPÍŠIL, Ivo: Srdce literatury. A. A. Vrzal, 1864-1930. Brno: Albert, 1993); VILINSKIJ, Sergij: Skazanije černorizca Chrabra o pismenech slavjanskich. Odessa: Ekonomičeskaja tipografija při Novorossijskom universitete, 1901; týž: Poslanije starca Artemija XVI veka. Odessa: sine 1906; V Bolgarii v 1920-1923 gg. In: Iz emigrantskich pereživanij. Jubilejní sborník Svazu ruských studentů v Brně. Brno: Sojuz russkich studentov, 1932; Vizantijsko-slavjanskije skazanija o sozdanii chrama sv. Sofii caregradskoj. Odessa: Ekonomičeskaja tipografija při Novorossijskom universitete, 1900; Žitije sv. Vasilija Novago v russkoj literature. Odessa: sine 1913; Dílo P. Augustina Vrzala. Archa XVII, Olomouc 1929, s. 229-238. Viz MANDÁT, Jaroslav: Vzpomínka na S. G. Vilinského. In: Sborník prací filozofické fakulty Masarykovy univerzity, D 33, 1986, XXXV; POSPÍŠIL, Ivo: Alois Augustin Vrzal: A Catholic Vision of Slavonic Literatures. Slovak Review, 1992, č. 2, s. 166-171; týž: Alois Augustin Vrzal a jeho duchovni dědictví. Universitas, 1992, 6, s. 27-30; Alois Augustin Vrzal: Koncepce a dokumenty. In: Sborník prací filozofické fakulty brněnské univerzity, D 40, 1993, s. 53-62; Srdce literatury. Alois Augustin Vrzal, 1864-1930. Brno: Albert, 1993; Sergij Vilinskij an der Masaryk-Universität in Brünn: Fakten und Zusammenhänge. Wiener Slavistisches Jahrbuch, Bd. 42, 1996, s. 223-230; Významné osobnosti naši univerzity. Zakladatel literárněvědné rusistiky na Masarykově univerzitě (Sergij Grigorovič Vilinskij, 1876-1950). Universitas, 2000, č. 1, s. 36-38; Dva moravští slavisté: Alois Augustin Vrzal a Sergij Grigorovič Vilinskij. Slavia Occidentalis 57, Poznań 2000, s. 219-233; Izmenenije temy i metoda - Sergij Vilinskij v Universitete im. Masarika. Russkij jazyk kak inoslavjanskij (http://www.slavistickodrustvo.org.rs/izdanja/RJKI.htm), vypusk IV. Beograd: Sovremennoje izučenije russkogo jazyka i russkoj kultury v inoslavjanskom okruženii, Slavističeskoje obščestvo Serbii, 2012, s. 7-19.

3 Viz ŽÁČEK, Pavel: V-101 (Valerij Vilinskij): agent, ze kterého se dalo žit. In: MEDVECKÝ, Matej (ed.): Posledné a prvé slobodné(?) vol'by - 1946, 1990. Zborník z odborného seminára. Bratislava: Ústav pamäti národa, 2006, s. 102-159; KAPLAN, Karel: Protistátni bezpečnost. 1945-1948. Historie vzniku a působeni STB jako mocenského nástroje KSČ. Praha: Plus, 2015; DVOŘÁKOVÁ, Jiřina: Státní bezpečnost v letech $1945-1953$. 
krize byl klíčovou postavou. Badatele v různých archivech čeká jistě hodně práce: spíše zarazí nepropojenost těchto bádání, nebot ve studiích archívu bezpečnostních složek nenajdeme ani stopy po identifikaci této osoby v širším slova smyslu, tedy to, že V. V. byl synem profesora Masarykovy univerzity a že byl významným publicistou, kulturologem a literárním vědcem. Zatímco bádání o jeho roli agenta a potom i vězně (jeho řídícím důstojníkem byl neslavně známý Brňan Bedřich Pokorný - nar. 1904, v březnu 1968 se v prostoru brněnské přehrady oběsil), ponecháme odborníkům na tuto oblast, Vilinského práce odborné a publicistické, byt již byly s německou důkladností analyzovány ${ }^{4}$, stojî ještě před politology, kulturology a literárními vědci jako naléhavý úkol; nelze je odbýt několika povšechnými větami v souvislosti s angažmá autora $\mathrm{v}$ tajné policii.

Zmiňujeme se zde pouze o některých publikacích, které považujeme za stěžejní. Valerij Vilinskij ovládl především oba jazyky první Československé republiky, psal česky i slovensky, samozřejmě některé práce jsou překlady a lze předpokládat české a slovenské korektury ale - na rozdíl od svého otce - se silněji přizpůsobil domácímu prostředí. Také navázal mnohem užší styky s církevními, zejména katolickými kruhy a snažil se z hloubi poznat situaci tehdy nového státu, na jehož budoucnost pohlížel sice jakoby optimisticky, snad i z hlediska taktiky, ale také skepticky, nebot̉ netrpěl iluzemi ze sporů česko-slovenských, z role menšin, hlavně německé a mad’arské, a chyb pražské politiky. Právě to se stalo tématem jeho skvělé knihy Rus se dívá na $\breve{C}$. $S$. $R .{ }^{5}$ Zajímavé je, že jako na náboženství orientovaný badatel, literární vědec, kulturolog, snad i teolog a religionista, zkoumal právě náboženské poměry v ČSR, nemohl si nevšímat sporů vládní moci v Praze s katolickou církví i zcela jiné situace na Slovensku a specifika Podkarpatské Rusi, o níž zcela samozřejmě klidně uvažoval, že se v blízké budoucnosti stane součástí bud' samostatné Ukrajiny, nebo SSSR či nového Ruska. Velmi přesvědčivé jsou jeho analýzy katolické církve, ale také česko-slovenského vztahu. Jako svou misi chápal Valerij Vilinskij nutnost informovat střední Evropu o Rusku. To se mu podařilo zvláště v knize $V$ Rusku boj trvá, ${ }^{6}$ v zevrubně koncipované studii Ruské revoluce 1825-1936 a v knize o typech slovanské vzájemnosti, kterou viděl velmi realisticky a diferencovaně. ${ }^{7}$ Vztahem mezi ruským národem a možným sjednocením církví se zabýval v knize vydané v Olomouci roku 1928, kterou jako pravoslavný Rus dedikoval katolické církvi. ${ }^{8}$ Informacemi nasycené a koncepcemi hýŕící jsou také jeho práce o duchu ruské církve, duchovním životě ruského

Praha: Úřad dokumentace a vyšetřování zločinů komunismu, 2007; PUTNA, M. C.: Hořký život Rusů $v$ Čechách. http://www.lidovky.cz/putna-horky-zivot-rusu-v-cechach-do8-/nazory.aspx?c=A111118_183244_ ln_nazory_ape, staženo 13. 8. 2016.

4 HULTSCH, Anne: Ein Russe in der Tschechoslowakei. Leben und Werk des Publizisten Valerij S. Vilinskij (1903-1955). Köln: Böhlau, 2010.

5 Viz některá česky vydaná díla Valerije Vilinského: Ruský národ a sjednoceni církví. Olomouc: Nákladem Apoštolátu sv. Cyrila a Metoděje pod ochranou bl. Panny Marie vytiskly Lidové závody tiskařské, 1928; K slovanské otázce. Tři koncepce slovanské vzájemnosti. Praha: Václav Petr, 1930; V Rusku boj trvá... (Politické vraždy, procesy a spiknutí v SSSR). Praha: Naklad. Šolc a Šimáček, s. r. o., 1933; Ruská revoluce 1825-1936. Přerov: Vydáno nákladem knihkupectví společenských podniků, 1936.

6 Viz výše.

7 Viz výše.

8 Viz výše. 
národa a rusky psaná publikace o kořenech jednoty ruské kultury. ${ }^{9}$ Valerij Vilinskij byl člověk skutečně všestranný, a to můžeme vzhledem k výše napsanému myslet i ironicky, ale zajímavý je i jeho humoristicko-satirický román Mařenka chce jinou vládu. ${ }^{10}$ Podnětná je také jeho úvaha o stavu náboženství v SSSR, ${ }^{11}$ ještě průraznější jeho studie o ruském katolicismu, ${ }^{12}$ stejně jako práce o možném sjednocení církví. ${ }^{13}$ Slovensky vyšla Ruská revolúcia a kniha o unionismu. ${ }^{14}$ Téma unionismu spojoval také se slovanství a hnutím Orel. ${ }^{15}$

Samostatnou kapitolou jeho činnosti jsou studie o české katolické literatuře, zejména o Otokaru Březinovi (1868-1929), Jaroslavu Durychovi (1886-1962) a Jakubu Demlovi (1878-1961), které př́íznačně publikoval v Polsku polsky, ${ }^{16}$ ale, jak sám uvádí v knize Rus se dívá na $\check{C}$. S. $R,{ }^{17}$ psal např. o Durychovi i jinde. Jsou to velmi samostatné, spíše esejistické analýzy, které by si zasloužily zvláštní pozornost. Podivná je jeho ignorance klíčových proudů tehdejší literatury, které však měly silně levicový ráz (proletářská poezie, expresionismus, futurismus, poetismus, konstruktivismus, surrealismus). Možná právě z této konfrontace mohlo vzejít i něco ještě přínosnějšího, nebot’ oba tábory tvořící v liberálním prostředí se do značné míry tolerovaly, ale také se všelijak osobnostně prolínaly.

Postupně se blíže podíváme na jeho dva eseje z knihy Rus se dívá na $\check{C}$. S. R., a to o Jaroslavu Durychovi a Jakubu Demlovi, potom tyto úvahy doplníme jeho polskými publikacemi, které se týkají více podobně zaměřených autorů se zřením se závěry německé monografie o V. Vilinském z pera Anne Hultschové. ${ }^{18}$ Valerij Vilinskij má právní a obecně humanitní vzdělání, ale je to především novinář. To se kladně i záporně projevuje právě v jeho pojednáních o některých českých spisovatelích. Již jejich volba není literární, ale náboženská: vybírá si české katolické autory, kteří jsou podle něho v osobité enklávě

9 VILINSKIJ, Valerij: Duch ruské církve. Praha: Ladislav Kuncír, 1930; Duchovní život ruského národa. Praha: Naklad. V. Kotrba, 1931; Korni jedinstva russkoj kultury. Užgorod: Kuĺturno-prosvetiteĺskoje obščestvo im. A. Duchnoviča, 1928.

10 VILINSKIJ, Valerij: Mařenka chce jinou vládu. Brno: Občanská tiskárna, 1933.

11 VILINSKIJ, Valerij: Pronásledováni náboženstvi v Rusku. Hlučín ve Slezsku: Exerciční dům, 1930.

12 VILINSKIJ, Valerij: Čerty ideologii russko-katoličeskogo dviženija. Užgorod: Apostolat sv. Kirilla i Mefodija 1928.

13 VILINSKIJ, Valerij: O sjednoceni církvi. Hlučín ve Slezsku: Exerciční dům, 1928.

14 VILINSKIJ, Valerij: Ruská revolúcia. V rukopise poslovenčil Vojtech Hatala. Trnava: Spolok sv. Vojtecha, 1936; týž: Unionizmus. Do slovenčiny upravil Ladislav Šulgan-Lazovský. Trnava: Spolok sv. Vojtecha, 1932.

15 VILINSKIJ, Valerij: Slovanství, unionismus, orelstvo. Brno: Nákladem Čs. orla, 1932.

16 VILINSKIJ, Valerij: Otokar Březina. Przegląd Powszechny, Kraków, 1931, s. 71-86, 207-225; týž: Jaroslav Durych. Przegląd Powszechny, Kraków, 1930, s. 20-89; Jakub Deml. Przegląd Powszechny, Kraków, 1933, s. 285-301. Viz POSPÍŠIL, Ivo: Singularity and the Czech Interwar Essay among the Currents: František Xaver Šalda, Karel Čapek, and Jaroslav Durych. Primerjalna književnost 33, Ljubljana, 2010, č. 1, s. 131-142; týž: Pavol Strauss a hrst českých souvislostí. In: Pavol Strauss a katolícka moderna. Ed. Ján Gallik. Nitra: Ústav stredoeurópskych jazykov a kultúr, Fakulta stredoeurópskych štúdií, Univerzita Konštantína Filozofa, 2014, s. 91-109.

17 VILINSKIJ, Valerij: Rus se dívá na Č. S. R. Praha: Václav Petr, 1931, s. 67: „O Durychovi jsem už psal rusky, polsky $i$ česky a budu psát $i$ v jiných jazycích."

18 HULTSCH, Anne: Ein Russe in der Tschechoslowakei. Leben und Werk des Publizisten Valerij S. Vilinskij (1903-1955). Köln: Böhlau, 2010. 
nebo ghettu volnomyšlenkářské první republiky spolu s de facto vládní protestantskou koncepcí českých dějin. Katolictví mu jako pravoslavnému konvenuje jako prakticky každému pravoslavnému (nehledě na podstatné vnitřní rozpory), zejména Rusovi, svou univerzalitou, za níž se skrývá stín Dostojevského všečlověka, pozdější euroazijské chápání pozice Ruska: odtud Vilinského úvahy o sjednocení křestanských církví, zvláště katolické a pravoslavné; ačkoli o to napsal celé studie, jeho představa není přiliš jasná. Vycházíme nejprve z letmo načrtnutých pojednání, jež se staly součástí jeho knihy o Rusovi, jenž se dívá na Československo.

Partie o Jaroslavu Durychovi a Jakubu Demlovi jsou součástí druhé kapitoly s názvem Katolické ghetto, která obsahuje portréty různých osobností katolického života v tehdejší ČSR, včetně pasáže o jezuitech. Zatímco ostatní náboženské denominace jsou „odbyty“ následující souhrnnou kapitolou, katolíkům je věnováno podstatně více místa, a to nehovoříme o kritických poznámkách věnovaných např. československé církvi, protestantům a českým pravoslavným.

První „spisovatelská“ kapitola pojednává o Jaroslavu Durychovi. Jako zkušený novinář začíná Vilinskij in medias res, a to scénou z kavárny: „Sarkastickému úsměvu Jaroslava Durycha lze se denně podivovati v olomoucké kavárně ,Grand, krajni stolek v levém rohu, tak asi kolem druhé hodiny odpoledni. Trůni tam vy̌šsi, ale málomluvná bytost. Jeho nadšeni ctitelé řikají, že tento úsměv jest jedna z největšich přirodnich krás Československé republiky a může být pririovnán jedině $k$ úsměvu Anny Ondrákové. “19 Poněkud „bulvární“ incipit pak pokračuje líčením různých Durychových tváří (boj proti církevnímu činiteli, antivolnomyšlenkář, voják a lékař apod.). Nicméně dokázal vyhmátnout podstatnou stránku Durycha-spisovatele, když napsal: „Jaroslav Durych má dvě základny pro svou tvorbu: jedna je zcela empirická, hmatatelná, řekněme př́mo - česká. Druhá je transcendentni, závratně povýsená nad podminky nicotné empirie, pozdvižená nad prostorem i časem. “20 To souvisí se známou koncepcí Reného Wellka, který chápe vývoj české a anglické literatury i jako spor spirituálního a materiálního, empirického proudu, jak ostatně doložila i jeho habilitace napsaná během stáže na Harvardově univerzitě Immanuel Kant in England. ${ }^{21}$ Není to vzdáleno ani nedávno vysmívaným úvahám o české tzv. pozemské poezii z pera Milana Blahynky, at' již šlo o osobnosti, koncepce a kontexty sebevzdálenější - a možná jen zdánlivě. ${ }^{22} \mathrm{~V}$. Vilinskij s odkazem na Pavla Eisnera ukazuje Durycha jako českého „anti-Švejka“, jako, jak ř́ká, „rehabilitátora“ své vlasti, ale vzápětí dodává: kdyby měl více pokory.

Portrét Jakuba Demla je poněkud hlubší, detailnější a procítěnější. Na počátku je satira na Demlovy neustálé změny názorů: jednou je se sokolstvem, podruhé je zavrhne, totéž s Josefem Florianem apod. Implicitním klíčem k Demlovi je Vilinskému soustava jeho Šlépěji což je příznačné a svým způsobem dobově novátorské a vlastně do značné

19 VILINSKIJ, Valerij: Rus se dívá na Č. S. R. Praha: Václav Petr, 1931, s. 66.

20 Tamtéž, s. 68.

21 POSPÍŠIL, Ivo - ZELENKA, Miloš: René Wellek a meziválečné Československo. Ke kořenům strukturální estetiky. Brno: Masarykova univerzita, 1996; WELLEK, René: Immanuel Kant in England: 1793-1838. Harvard University Press, 1931.

22 BLAHYNKA, Miroslav: Pozemská poezie. Kapitoly k české poezii (1945-1975). Praha: Československý spisovatel, 1977. 
míry dosud, nebot častěji se odkazuje k jiným částem Demlova díla jako k působivějším. Jako Rus vidí Vilinskij v Demlovi něco, jak říká „z východní duše“, a využije toho ke kontrastnímu srovnání s Durychem: „V jeho dopisech, které tak rád uveřejňuje, v jeho snech, visích, básnich a v prose je viděti pathos boje - Deml vždy roste a mohutni. V tom zrcadli se nejenom gotický, nýbrž také východni prvek jeho duše. Gotika je bližši východu nežli pozdějši epochy a slohy. Deml nezná rozdilu mezi cílem a prostředkem a nedovedl zhodnotiti prostředek tak, aby odpovidal významu cile někdy snad nepatrného a podružného, jest ochoten střileti z děla na komára, vrážet do otevřených dveři, chtíti utrpeni a vymáhati mučednictvi na lidech, kteři nemaji nejmenšiho úmyslu jej pronásledovati [...] V Demlovi bije cit jako královská tepna - všude převládá duše. Je to východni rys povahy, který jej přibližuje Rusům, a neni divu, že Polák Zegadtowicz (Emil Erwin Zegadłowicz, 1888-1941, polský expresionista, básník, prozaik, dramatik, publicista, překladatel, mimochodem potomek jihočeských vystěhovalců; svým českým kořenům věnoval básnický cyklus Budějovické louky, Praha: Vyšehrad, 1934, takže je otázka, nakolik se od Čechů liší - ip), v němž jsou východni a západni prvky harmoničtěji sloučeny než v Češich, dává přednost Demlovi před Durychem. U Durycha je až př́liš mnoho rozumu..." ${ }^{23}$

Podstatně podrobněji se „svými katolíky“ Valerij Vilinskij zabývá ve svých polsky psaných studiích. ${ }^{24} \mathrm{~V}$ rozsáhlé práci o Otokaru Březinovi se v první části věnuje portrétu a osudu básníka, který, jak si všímá, dosáhl už za života slávy nejen v prostředí českém a československém, ale i v zahraničí, a ukazuje na jeho překlady do polštiny. V druhé části se ponořil do analýzy zejména jeho básnických sbírek. Březinův význam vidí především v duchovním přesahu a v tom, že položil základy původní a působivé duchovní literatury, k níž patřili další dva Vilinského oblíbenci - Jaroslav Durych a Jakub Deml. Tuto etapu považuje Vilinskij nejen za další, ale i za vyšší. ${ }^{25}$ Studie o Durychovi je sevřenější, i když má také dvě části rozdělené jako obvykle na osobnostní portrét a analýzu díla. Zde Vilinskij šíře a hlouběji dokládá svou tezi o dvojí povaze Durychova díla jako empirického a duchovního. V jakémsi dualismu také spočívá jeho osobitost, a to se týká také napětí mezi národním, českým a univerzálním, transcendentním: tyto dvě strany nejsou od sebe odděleny, ale duchovno, transcendentno je přímou podstatou empirických detailů. Pravděpodobně právě v Demlovi spatřuje Vilinskij jistý vrchol katolického literárního úsilí. Jemu věnuje rozsáhlou studii, jejíž první část nazval Básnik a lidé. V ní rozebírá vztah Čechů a české literatury k náboženské víře a již na počátku prohlašuje, že žádná literatura, snad kromě ruské, se náboženským otázkám nevěnovala více, i když Češi sami byli často heretiky nebo právě proto. Studie o Demlově díle patří ve sféře literární kritiky patrně k tomu nejlepšímu, co Valerij Vilinskij kdy napsal. Důvodem je asi ustrojení jeho osobnosti podobné Demlově - alespoň v některých rysech - rozpornosti, radikality, ale i smyslu pro groteskno, absurdno a současně duchovní přesah, tedy ta podivuhodná moderní směs vysokého a nízkého, gravitas a komiky, klidu a hněvu, ${ }^{26}$ která

23 VILINSKIJ, Valerij: Rus se dívá na 亡̌. S. R. Praha: Václav Petr, 1931, s. 74.

24 Viz jeho studie Otokar Březina. Przegląd Powszechny, Kraków, 1931, s. 71-86, 207-225; týž: Jaroslav Durych. Przegląd Powszechny, Kraków, 1930, s. 20-89; Jakub Deml. Przegląd Powszechny, Kraków, 1933, s. $285-301$. Otokar Březina. Przegląd Powszechny, Kraków, 1931, s. 224.

26 Viz POSPÍŠIL, Ivo: Žánr jako bezprostředni výraz autorovy osobnosti. Denik spisovatele F. Dostojevského a Šlépěje J. Demla. Slovenská literatúra, 1990, č. 4, s. 338-349. 
je charakteristická pro některé náboženské literární proudy, včetně katolických, jichž je Deml nejlepším představitelem.

Anne Hultsch ve svém jedinečném, obsáhlém a důkladném spise o Valeriji Vilinském si těchto studií všímá sice okrajově, ale současně s recepcí jeho názorů $\mathrm{v}$ českém prostředí. Uváděné autory dává do souvislostí s celým Vilinského konceptem katolictví jako československého ghetta, kde u ní vedle sebe figurují Josef Florian, Jaroslav Durych, Jakub Deml, Alfred Fuchs, Andrej Hlinka a Augustin Vrzal. ${ }^{27}$ Metodologicky tu V. Vilinskij stojí blízko duchovědných přístupů, jež nebyly literární vědě v českých zemích cizí, spíše naopak.

V polsky psaných studiích, jimiž Vilinskij - zjevně z rodu polského původu - působivě šíril znalosti o vysoké kvalitě české literatury, je řada pasáží, které vycházejí z polského recepčního prostředí, jak je předpokládal, a to tak, aby čtenářstvu s jinými tradicemi vysvětlil podivuhodnosti českého duchovního přesahu v katolické literatuře, která byla $\mathrm{v}$ českém prostředí sice respektovanou, ale přece jen slabší než celý proud levicové avantgardy. To, co Valerij Vilinskij bohužel propásl, byla př́ležitost ukázat, jak se v některých osobnostech tyto proudy spojovaly, nacházely blízkost a navzájem se zrcadlily. Ve třicátých letech 20. století byly výsledky Demlova působení na zrající generaci mladých českých básníků avantgardy zcela zřetelné, i když ještě nebyl znám Nezvalův zákrok v Demlův prospěch po roce 1945, jenž tuto spojitost i vděčnost tím nejušlechtilejším způsobem potvrzoval.

Jak uvádíme na počátku studie v souvislosti s jeho zoufalými poválečnými léty, Valerij Vilinskij se narodil do zlé doby, kdy hrál doslova - jistě pod značným nátlakem - o život, který však za strašnou cenu uhájil stejně jen na pár let. Je zřejmé, že tehdy mohl na své okolí působit jako všehoschopný cynik, ale my si dnes zatím nedovedeme tyto situace dost dobře představit. Toto at̉ soudí jiní, nebot: „Nesud'te, abyste nebyli souzeni“ (Matouš 7:1). At tak či onak, zůstalo z jeho pera dost dobrých textů, které jsou nejen svědectvím o činnosti ve střední Evropě, ale také vědeckým př́nosem, často s přidanou hodnotou vizionářskou: je s podivem, jak některé jeho koncepce předvídaly budoucí události a obnažovaly skryté mechanismy vývoje, včetně literárního.

\section{prof. PhDr. Ivo Pospíšil, DrSc.}

Ústav slavistiky

Filozofická fakulta, Masarykova univerzita

Arna Nováka 1, 60200 Brno, Česká republika

ivo.pospisil@phil.muni.cz

27 HULTSCH, Anne: Ein Russe in der Tschechoslowakei. Leben und Werk des Publizisten Valerij S. Vilinskij (19031955). Kölh: Böhlau, 2010, s. 112-144. Autorka si všímá i našich studií o Sergiji Vilinském a A. A. Vrzalovi (A. G. Stin). 
